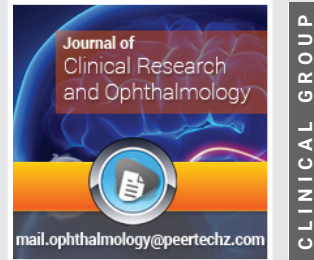

\title{
Brief review of HLA profile and clinical presentation of multiple sclerosis in Iran
}

\section{Hossein Kalanie*}

Professor, Neurologist, Beheshti University school of medical sciences, Mehr Hospital, Zartoosht

Street, Tehran, Iran

HLA typing, the natural course and clinical findings of 79 and 200 definite MS cases in Iran was respectively reviewed $[1,2]$.

Results drawn from our 79 Iranian MS patients revealed an association between MS and HLA types A 24, DR 2, and DR 15, each with a relative risk of 1.9 times of controls.

This genetically determined increased risk is best explained by assuming the existence of an MS susceptibility gene which has been identified in linkage studies with HLA DR 15 and DR 2 loci on chromosome 6. This association of DR 2 and DR 15 HLA types with MS in Iranian patients is in line with studies done in other parts of the word [3-6].

In the analysis of HLA class 1 , we found a positive association with A 24 but no association with B locus alleles. The association of HLA-A locus in Iranian MS differs from previous studies in other parts of the world $[4,7,8]$ as well as Asian countries $[9,10]$.

In fact, Indian investigators identified an association between HLA B12 and MS [9].

Of interest is under-representation of the following alleles in Iranian MS patients: HLA-A28, B5, B14, CW2 $(\mathrm{p}<0.05)$ and HLA B15, B 40, DR-4, DR-52, and DQ3 (p<0.005).

Whether thede alleles have any protective role against MS in this geographic region to be determined.

Iran is traditionally thought to be situated in a low risk zone for MS [2], but currently the incidence of the disease has been raising.

In Iran MS presents with involvement of multiple sites in the Central Nervous System (CNS) including the cerebrum, cerebellum or brain stem, which is similar to its behavior in the Caucasian population. Having the relapsing- remitting MS (RRMS) as the most frequent type of presentation, followed by Primary Progressive (PPMS) form with a higher age at onset and worse prognosis, and female preponderance, in both types are in agreement with European and Latin American studies [11-14]. The most common presenting symptoms of pyramidal and sensory involvement in the present cases have also been reported from neighboring Middle East countries and Europe $[11,15]$. Compared with RR group, Secondary Progressive (SPMS) had more annual attacks with pyramidal or cerebellum dysfunction as their presenting signs. The 28 patients with EDSS score 3 after 10 years and 24 with EDSS score 2 after five years indicate a benign course for MS in this country.

Optico-spinal MS (OSMS) which is a common presentation of the disease in Asian countries and is called Asian type [16], is not a prominent feature here, probably due to different

HLA typing. Three percent of our patients suffered from specific firm of OSMS which has different features compared to Asian ones $[17,18]$. In which a paucity of brain lesions was accompanied by short spinal segment involvement. It has a benign course with negative.

CSF oligocolonal band and different HLA from conventional MS.

It is believe that we are facing a raising incidence of MS similar to other countries [14-19].

This may be explained by increased survival, and improved laboratory and radiological diagnosis. However a decreased number with SP form which is a natural endpoint of the RR 
type may indicate that more new cases are being diagnosed. However other possibilities should be looked for.

\section{References}

1. Kalanie H, Kamgooyan M, Sadeghian H, Kalanie AR (2000) Histocompatibility antigen association with multiple sclerosis in Iran. Mult Scler 6: 317-319. Link: https://bit.ly/3gewP85

2. Kalanie H, Gharagozli K, Kalanie AR (2003) Multiple Sclerosis: Report on 200 cases from Iran. Mult Scler 9: 36-38. Link: https://bit.ly/3dJhBWE

3. Francis DA and the British \& Dutch multiple sclerosis azathioprine trial group (1988) Histocompatibility antigens in multiple sclerosis patients participating in a multicentre trialof azathioprine. J Neurol Neurosurg psych 51: 412-415. Link: https://bit.ly/2ZiGK5A

4. Alvarado-dc La Barrera C, Zuntig-Ramos J, Ruiz-Norales JA, Estañol B, Granados J, et al. (2000) HLA class II genotypes in Mexican Mestizos with familial and non-familial multiple sclerosis. Neurology 55: 189-190. Link: https://bit.ly/38b4AnE

5. Pina MA, Ara JR, Lasierra P, Modrego PJ, Larrad L (1999) Study of HLA as a predisposing factor and its possible influence on the outcome of multiple sclerosis in the sanitary district of Calatayud, north Spain. Neuroepidemiology 18: 203-209. Link: https://bit.ly/2ZkJHSZ

6. Odinak MM, Bisaga GN, Kalinina NM (2000) Multiple sclerosis in north -west region of Russia: Results of HLA typing. Zh NevrolPsikhiatr Im S S Korsakova 100: 404 .

7. Shiralieva RK, Guseinova KA (1998) Characteristic of histocompatibility antigens distribution in patients with multiple sclerosis. Klin Med Mosk 76: 19-20. Link: https://bit.ly/2CUldHT

8. WadiaNH, Trikannad VS, Krishnaswamy PR (1980) Association of HLA-B12 with multiple sclerosis in India. Tissue Antigens 15: 90-93. Link: https://bit.ly/2ZhZbY5

9. Wadia NH, Trikannad VS, Krishnaswamy PR (1981) HLA antigens in multiple sclerosis amonges Indiands. J Neurol Neurosurg Psychiatry 44: 849-851. Link: https://bit.ly/3i5zAKq
10. Ono T, Zambennedetti MR, Yamasaki K, Kawano Y, Kamikawaji N, et al. (1998) Molecular analysis of HLA class I (HLA_A and B) HLA class II(HLA_DRB1) genes in Japanese patients with multiple sclerosis (Western type and Asian type). Tissue Antigens 52: 539-552. Link: https://bit.ly/3gcMggH

11. Moreira MA, Felipe E, Mendes FM, Tilbery CP (2000) Multiple sclerosis descriptive study of its clinical forms in 302 cases. Arq Neuropsiquiatr 58: 460-466. Link: https://bit.ly/31nN6mV

12. Berne-Bernady P, Preux PM, Preux C, Dumas M, Vallat JM, et al. (2000) Case study of 199 patients with multiple sclerosis: The use of EDMUS program. Rev Neurol 156: 41-46. Link: https://bit.ly/2VwEVku

13. Arruda WO, Scola RH, Teiva HA, Werneck LC (2001) Multiple asclerosis report on 200 cases from Curitibam, Southern Brazil, comparison with other brizilian series. Arq Neuropsiquitr 59: 165-170. Link: https://bit.ly/2Bb5FjB

14. Mc donnell GVMc, Hawkins SA (1998) An epidemiologic study of multiple sclerosis in northern Ireland. Neurology 50: 423-428. Link: https://bit.ly/3gc4yyX

15. Daif AK, Al-Rajeh S, Awada A, Bunyan MAl, Ogunniyi A, et al. (1998) Pattern of presentation of multiple sclerosis in Saudi Arabia: Analysis based on clinical and paraclinical features. Eur Neurol 39: 182-186. Link: https://bit.ly/38f7zLV

16. Kira J, Kanai T, Nishimura Y, Yamasaki K, Matsushita S, et al. (1996) Western versus asian types of multiple sclerosis: Immunogenetically and clinically distinct disorder. Ann Neurol 40: 569-574. Link: https://bit.ly/3g6chOS

17. Kalanie H, Kholghi Y, Reza shamsai G, Ghorbani M (2009) Opticospinal multiple sclerosis in Iran. J Neurol Sci 276: 130-132. Link: https://bit.ly/3g9aBUI

18. Kalanie H, Kamgooyan M, Kholgi Y, Harandi A, Hosseinzadeh Z (2011) HLA allele frequencies in Iranian Opticospinal multiple sclerosis. J Biomed Science 4: 511-515. Link: https://bit.ly/31siUa4

19. Syal P, Prabhakar S, Thussu A, Sehgal S, Khandelwal N (1999) Clinical profil of multiple sclerosisin north-west India. Neurl India 47: 12-17. Link: https://bit.ly/2VsWYrP
Discover a bigger Impact and Visibility of your article publication with

\section{Peertechz Publications}

\section{Highlights}

* Signatory publisher of ORCID

* Signatory Publisher of DORA (San Francisco Declaration on Research Assessment)

* Articles archived in worlds' renowned service providers such as Portico, CNKI, AGRIS, TDNet, Base (Bielefeld University Library), CrossRef, Scilit, J-Gate etc.

* Journals indexed in ICMJE, SHERPA/ROMEO, Google Scholar etc.

- OAI-PMH (Open Archives Initiative Protocol for Metadata Harvesting)

* Dedicated Editorial Board for every journal

* Accurate and rapid peer-review process

* Increased citations of published articles through promotions

- Reduced timeline for article publication

Submit your articles and experience a new surge in publication services (https://www.peertechz.com/submission).

Copyright: (c) 2020 Kalanie $\mathrm{H}$. This is an open-access article distributed under the terms of the Creative Commons Attribution License, which permits unrestricted use, distribution, and reproduction in any medium, provided the original author and source are credited. 